\title{
Design and Implementation of a Capstone Course to Satisfy the Industry Needs of Virtual Product Development and ABET Engineering Criteria
}

\author{
Mohamed A. Omar \\ Mechanical Engineering Department, Taibah University, Almadinah Almonawwarah 42353, Saudi Arabia \\ Correspondence should be addressed to Mohamed A. Omar; momar@taibahu.edu.sa
}

Received 6 January 2014; Accepted 8 February 2014; Published 25 May 2014

Academic Editor: Gwo-Jen Hwang

Copyright (C) 2014 Mohamed A. Omar. This is an open access article distributed under the Creative Commons Attribution License, which permits unrestricted use, distribution, and reproduction in any medium, provided the original work is properly cited.

Over the past two decades, computer aided engineering (CAE) processes and procedures became an integral part of the product development cycle. Virtual product development (VPD) refers to procedures that integrate the CAE tools in a unified approach that spans all the product development phases. Current industrial trends utilize VPD tools and procedures to reduce the product development time without jeopardizing the product quality. These trends led to an increasing demand for engineers with computer skills, multidisciplinary engineering knowledge, and acquaintance with VPD tools. ABET program outcomes emphasize providing courses with an accumulated background of curricular components to solve realistic open-ended engineering problems. Capstone design project (CDP) course has been regarded as important learning activity that could be designed to provide senior engineering student an opportunity to solve such problems. A major objective of the CDP course is to simulate industrial setting and allow students to experience real-life engineering practice. This paper presents an implementation of the VPD procedures in a mechanical engineering CDP course. This integration simulates the industrial environment through multidisciplinary teams working together in subsystems to produce one product using standard commercial VPD tools. This course implementation is demonstrated using a case study of teams working to design and build a solar car.

\section{Introduction}

Engineering education is a dynamic continuously evolving process that responds to the job market and industrial needs. It adopts new plans, strategies, and technologies to produce a well-integrated engineer with a set of fundamental professional competencies. Professional societies often conduct market surveys to probe the industry needs while, in the meantime, define the futuristic vision of the profession. The professional societies communicate their findings to educational institutions and accreditation agencies. The accreditation agencies compile these requirements into guidelines for the educational institutions where engineering education program developers adapt the program study plans and curricula contents in response to those guidelines. In order to be accredited, the academic program objectives may be aligned with the guidelines of the accreditation agencies, for example, ABET, European Network for Accreditation of Engineering Education (ENAEE), Engineering Accreditation Council (EAC), and so forth. Table 1 shows example of the students outcomes developed by ABET for the engineering programs. ABET emphasizes the need for engineering curricula to include components that allow the students to identify, formulate, and propose engineering solutions to solve industrial problems as well as contemporary social or global problems. Teaching the students engineering design process that will satisfy the industry needs requires developing a set of fundamental skills. This procedure may require integrating the knowledge that has been acquired in different courses. The engineering design process could involve conducting experiments to evaluate the performance of the proposed solution or process. In order to produce an acceptable economical solution, the proposed design must fulfill the product standards and safety requirements of the region or 
TABLE 1: ABET students outcomes [4].

(a) An ability to apply knowledge of mathematics, science, and engineering

(b) An ability to design and conduct experiments as well as to analyze and interpret data

(c) An ability to design a system, component, or process to meet desired needs within realistic constraints such as economic, environmental, social, political, ethical, health and safety, manufacturability, and sustainability

(d) An ability to function on multidisciplinary teams

(e) An ability to identify, formulate, and solve engineering problems

(f) An understanding of professional and ethical responsibility

(g) An ability to communicate effectively

(h) The broad education necessary to understand the impact of engineering solutions in a global, economic, environmental, and societal context

(i) A recognition of a need for and an ability to engage in life-long learning

(j) A knowledge of contemporary issues

(k) An ability to use the techniques, skills, and modern

engineering tools necessary for engineering practice.

the country. Developing a competitive solution may require using the modern engineering tools and procedures. In order for teams to function properly, members have to discipline themselves and adhere to professional ethics. Developing the academic program that fulfills ABET requirements could become a challenging daunting task and leave some gaps. The capstone courses can aid in closing those gaps. The capstone courses have been widely implemented to aid in building and enhancing the skill sets mentioned above.

ABET outcome " $k$ " which requires "ability to use the techniques, skills, and modern engineering tools necessary for engineering practice" [1], is known to be a challenging goal in many aspects. Many academic programs consider fulfilling this outcome through teaching commercial software packages that can achieve acceptable results in certain aspects to fulfill the course outcomes. However, integrating these commercial packages into a holistic approach to form a problem solving procedure has been very limited and, in many cases, has not been taken into consideration. On the other hand, the industry is more interested in developing and following systematic integrated procedures from the early stages of product concept development till manufacturing and after sales services.

According to commercial surveys [2], designers face an increasing pressure and constraints that require special skills to achieve their tasks. More than $80 \%$ of the designers spend an average of $25 \%$ of their time on concept generation process compared to the total time required to design, develop, and manufacture a product. The concept generation process may consume up to $60 \%$ of the total fixed product cost. Most frequently, three design alternatives and concepts are to be explored during the concept design stage when developing a new product. In $60 \%$ of the cases, the time allocated for concept design process is cut short by about $30 \%$ due to schedule, while $35 \%$ of the product critical decisions are made during this stage. These data indicates the importance and benefits of reducing the time to create a concept design through VPD procedures. According to the author's opinion, capstone design course represents an excellent opportunity to expose the engineering students to these industrial challenges.

The capstone design course was developed and integrated in academic programs more than 50 years ago. Todd et al. [3] conducted a survey on capstone courses in engineering departments throughout North America in order to understand current practices in capstone education. This study was conducted in order to improve capstone experiences. The survey results were categorized into five major areas of interest: profile of the respondents, course description information, faculty involvement in capstone education, project information, and industrial involvement in capstone education. The survey results provide educators with an excellent foundation for developing a capstone design project courses and the associated skills.

Many educators have presented different proposals for a unified framework for the capstone design project from different prospective [4-17]. Beyerlein et al. [18] presented a framework for developing and implementing assessment instruments in capstone engineering design courses. The framework provides a structure for aligning learning outcomes and methods for examining performance related to these outcomes and providing feedback that improves student learning in these outcome areas. The framework incorporated the following three different perspectives: the educational researcher, the student learner, and the professional practitioner. In the meantime, Franchetti $[11,19]$ presented a framework for collaboration between university, industry and local civic institutions through the design clinic. Schmidt et al. [6] discussed the implementation of an open source course management system to provide a centralized virtual community for students, faculty and external participants. The implementation and necessary innovations and lessons learned were discussed and presented as a framework that could be replicated [20-33]. The above mentioned proposed frameworks were designed to train the students on solving specific industrial problems without any replication of the industrial process or procedures.

According to Todd and Maglebya [23], engineering education has a number of stakeholders including the industry, students, faculty, academic administrators, and others. In order to emphasis the need to match the industrial needs, Todd and Maglebya discussed alternative approaches to develop a capstone course. With input from those stakeholders, alternative approaches for developing CDP courses were proposed and evaluated in light of stakeholder needs and wants. Feedback from alumni on the success of this course in meeting the desired educational objectives was presented. A case study for developing a two-semester senior design capstone course at Brigham Young University was presented. Warda [20] conducted a study on the capstone programs implemented at the world's top-ranked engineering universities to discover common elements which characterize them. Warda identified and presented those common elements in mechanical and aerospace engineering undergraduate 
programs to determine and establish best practices. These practices can be modeled and applied to the pedagogy of engineering programs at universities around the world to improve the development of professional skills of future graduates. Kachra and Schnietz [25] presented a newly developed senior capstone design course entitled "Integrated Product and Process Design." The presented new capstone course is centered on industrial design and manufacturing projects. These projects involve both product and process design activities. Multidisciplinary teams of students are taught a structured development approach to produce typical industrial deliverables. These deliverables include a functional specification, product and process design, prototype, and first production sample.

The professional ethics subject was found to be one of the important topics that were discussed as part of the capstone project implementation [34-38]. According to Griffin et al. [39], team formation and selection are important activities that should be carefully administered to help the teams succeed in their projects. The assessment of the students' performance and the course outcomes was an integral part of the ongoing research on the capstone projects course $[18,40-$ 43]. In 2000, McKenzie et al. [22] conducted a two-phase study to better understand the nature and scope of assessment practices within capstone design courses across engineering disciplines, and, in particular, the extent to which current practices align with ABET EC 2000 expectations. According to the survey, faculty members report that some ABET EC 2000 criteria are currently not well assessed in capstone design courses. Findings also suggest uncertainty on the part of many faculty members concerning sound assessment practices, including writing objectives, using appropriate assessment strategies, sampling material appropriately, and controlling mismeasurement of student achievement. Beyerlein et al. [18] analyzed and compared various undergraduate final year engineering project assessment approaches of different universities in Australia. The research objective was to explore the best assessment practice for the delivery of final year project. This analysis compared the various types of final year projects undertaken, their learning outcomes, teaching methods, and assessment measures.

The above mentioned studies highlight the importance of preparing students with the tools that are most needed for the industry. This paper presents a focused attempt to develop such competencies through the capstone course. The paper describes comprehensive structure and detailed implementation of a capstone course that incorporates the VPD procedures using commercially available tools in a multidisciplinary mechanical engineering capstone projects. The course was implemented in a newly established ME program at Taibah University. This paper is organized as follows: the following section provides an overview of the academic program. Section 3 presents in detail the capstone course description and objectives. The relationship between the course outcomes and ABET students outcomes will be presented. The proposed structure of the capstone project course will be presented in Section 4. Integrating the VPD tools and procedure in the course will be explained in Section 5, while the challenges in this implementation will be presented in Section 6. Section 7 briefly discusses the student learning assessment. A case study of the proposed implementation will be presented in detail in Section 8 . A summery and some conclusions will be presented in Section 9.

\section{Overview of the Mechanical Engineering Program}

The educational goals of the mechanical engineering program is to provide a solid foundation of mathematical, scientific, and engineering knowledge and to develop the basic engineering competencies that will serve students throughout their careers. The program educational objectives are summarized under the following.

2.1. Foundations. To provide students with a strong foundation in mechanical engineering sciences and design methodologies that emphasize the application of the fundamental mathematical, scientific, and engineering principles in the areas of mechanical engineering.

2.2. Skills and Tools. To provide students with skills to enter the workplace well prepared in the core competencies listed below as follows.

(a) Ability to formulate and solve engineering problems.

(b) Ability to apply knowledge of mathematics and sciences to designing.

(c) Ability to apply experimental and data analysis techniques.

(d) Teamwork experience.

(e) Oral, written, and multimedia communication skills.

(f) Experience with contemporary computing systems and methodology.

2.3. Awareness and Professional Ethics. To provide students with knowledge of issues relevant to mechanical engineering practices, including ethical, professional, and contemporary issues; the impact of mechanical engineering on society; and the importance of continuing education and life-long learning in both technical and nontechnical areas.

\section{Capstone Course Objectives and Outcomes}

Capstone is a metaphor used to describe a final achievement that builds upon previous works and encapsulates them. Capstone projects are included in engineering curricula to integrate multidisciplinary subjects and teach professional skills that are difficult to impart in a traditional lectured course. Since these projects serve to transition students into professional engineers, they have a direct impact on a university's industry reputation and ranking. The capstone course is an opportunity for the student to participate in a realistic design process with a design team in a real-design challenge. The structure and conditions under which student 
will work are similar to those he/she will be exposed to after graduation as a practicing engineer in industry.

The capstone course is an intense engineering exercise which consists of a sequence of two courses that spans a full academic year. The objective of the course sequence is to provide a realistic experience in the practice of engineering design for senior mechanical engineering students. During this course sequence, students will work in teams as project consultants. The team will work for an industrial client or other agency to develop a solution for a real-life problem with guidance from representative of the client and a faculty advisor. The solution should include some components of engineering design. The course is culminated when the team formally reports the results and submits the deliverables to the client. This student activity is intended to simulate the environment an engineer would experience in an industrial setting. This means the team is understaffed, underfunded, and could be overworked.

The client expects to receive all of the proposed deliverables. Default on the list of deliverables results in an incomplete grade for the course. The incomplete grade remains until all of the deliverables are transferred. The students are mentored to successfully complete their projects. One important aspect that student must pay great attention to is meeting the project deadlines and adhering to the course guidelines. Failure to meet the deadlines and/or following the guidelines leads reduction in the students' grade. According to the course catalog description, the course objectives are as follows.

(1) To integrate knowledge acquired from the various basic courses and apply it to an open-ended design effort.

(2) To enable the student to generate a problem statement with clear objectives.

(3) To foster in the student the use of systematic techniques to generate alternative designs and select among them.

(4) To develop in the student project management skills such as budgeting, scheduling, and teamwork.

(5) To enhance the student's ability to communicate effectively at both oral and written levels.

(6) To instill in the student the use of proper engineering judgment guided by ethical, environmental, and professional considerations.

The first semester of the course contains a lecture to cover the new topics that students need to learn. According to Todd et al. [3] and Howe [21], the most frequently taught subjects in capstone classes include how to give oral presentations, creativity, concept generation, teamwork, project planning, economics, ethics, developing functional specifications, safety, and optimization.

According to [3], although almost all capstone design projects courses require written documentation, only $7 \%$ indicated that they taught student engineers how to produce written engineering documentation. Since communication and presentation are covered in other courses in the program as shown in Table 2, the capstone course does not emphasize on them. The topics taught in this course include: introduction to senior design capstone project course, principles of engineering design process, design ideation, quality function deployment (QFD), design iteration and analysis, project management-planning and budgeting, engineering ethics, safety, and using standards and codes.

3.1. Impact of the Capstone Design Project on Program Outcomes. The following is a list of the course outcomes; many are tied to ABET criteria.

(1) To be able to work in self-directed teams.

(2) To be able to communicate your work to others.

(3) To be able to create product specifications based on customer needs while recognizing environment, economic, and societal factors.

(4) To be able to perform a design of a system or product based on product specifications.

(5) To be able to generate design alternatives.

(6) To be able to evaluate design alternatives using both analytical approaches and engineering judgment.

(7) To be able to use engineering software packages in design activities.

(8) To be able to build a prototype within a specified time period and within a budget.

(9) To be able to test a prototype and compare its performance to design specifications.

(10) To be able to understand the ethical responsibility of an engineer in design.

The relationship between the course objectives and the ABET outcomes is shown in Table 3. It could be shown that the current objectives do not fulfill all ABET outcomes and there is an opportunity to improve the course.

\section{Proposed Implementation of Capstone Course}

The design and structure of capstone project course has been considered from two aspects: (1) how the course could help the academic program in fulfilling the ABET requirements $[22,26,30]$ and (2) what are the components necessary to fulfill the learning outcomes [4-7, 24-33]. The capstone project implementation could significantly vary based on the course objectives. Beyerlein et al. [18] classified the senior project learning into six categories. In order to achieve the course objectives listed in the previous section, the proposed course implementation spans more than one category of this classification and could be considered as hybrid learning process that focuses on: problem, project, and design.

In the problem based learning students are presented to a situation, a case, or problem as a starting point. The role of the coordinator is to supervise and facilitates the learning process rather than providing knowledge. In the problem-based scenarios students are encouraged to engage 
TABLE 2: Mechanical engineering study plan.

(a) First year (FRESHMAN)

\begin{tabular}{|c|c|c|c|c|c|c|c|c|c|c|c|}
\hline \multicolumn{6}{|c|}{ First semester } & \multicolumn{6}{|c|}{ Second semester } \\
\hline \multirow[t]{2}{*}{$\begin{array}{l}\text { Code and } \\
\text { number }\end{array}$} & \multirow[t]{2}{*}{ Course title } & \multirow[t]{2}{*}{$U^{*}$} & \multicolumn{2}{|c|}{$\begin{array}{l}\text { Contact } \\
\text { hours }\end{array}$} & \multirow[t]{2}{*}{ Prerequisite } & \multirow{2}{*}{$\begin{array}{l}\text { Code and } \\
\text { number }\end{array}$} & \multirow[t]{2}{*}{ Course title } & \multirow[t]{2}{*}{$U$} & \multicolumn{2}{|c|}{$\begin{array}{l}\text { Contact } \\
\text { hours }\end{array}$} & \multirow[t]{2}{*}{ Prerequisite } \\
\hline & & & $\mathrm{Lt}$ & $\mathrm{Lb}$ & & & & & $\mathrm{Lt}$ & $\mathrm{Lb}$ & \\
\hline MATH 101 & $\begin{array}{l}\text { General } \\
\text { Mathematics (1) }\end{array}$ & 3 & 3 & 0 & & MATH 201 & $\begin{array}{l}\text { General } \\
\text { mathematics (2) }\end{array}$ & 4 & 4 & 0 & MATH 101 \\
\hline PHYS 103 & Physics (1) & 4 & 3 & 3 & & PHYS 104 & Physics (2) & 4 & 3 & 3 & PHYS 103 \\
\hline CHEM 103 & Chemistry (1) & 4 & 3 & 3 & & CS 102 & Programming (1) & 3 & 2 & 2 & \\
\hline ENGL 103 & $\begin{array}{l}\text { English } \\
\text { Composition }\end{array}$ & 3 & 3 & 0 & & GE 102 & $\begin{array}{l}\text { Intro. to } \\
\text { Engineering Design }\end{array}$ & 2 & 1 & 3 & ENGL 103 \\
\hline \multirow[t]{3}{*}{ ARAB 101} & Arabic Language (1) & 3 & 3 & 0 & & ENGL 104 & $\begin{array}{l}\text { Technical } \\
\text { Communication }\end{array}$ & 3 & 3 & 0 & ENGL 103 \\
\hline & Total & 17 & & & & ISLS 101 & Islamic culture (1) & 2 & 2 & 0 & \\
\hline & & & & & & & Total & 18 & & & \\
\hline
\end{tabular}

${ }^{*} U$ : Credit units; Lt: Lecture hours; Lb: lab. hours.

(b) Second year (sophomore)

\begin{tabular}{|c|c|c|c|c|c|c|c|c|c|c|c|}
\hline \multicolumn{6}{|c|}{ First semester } & \multicolumn{6}{|c|}{ Second semester } \\
\hline \multirow{2}{*}{$\begin{array}{l}\text { Code and } \\
\text { number }\end{array}$} & \multirow[t]{2}{*}{ Course title } & \multirow[t]{2}{*}{$U$} & \multicolumn{2}{|c|}{$\begin{array}{l}\text { Contact } \\
\text { Hours }\end{array}$} & \multirow[t]{2}{*}{ Prerequisite } & \multirow[t]{2}{*}{$\begin{array}{l}\text { Code and } \\
\text { number }\end{array}$} & \multirow[t]{2}{*}{ Course title } & \multirow[t]{2}{*}{$U$} & \multicolumn{2}{|c|}{$\begin{array}{l}\text { Contact } \\
\text { Hours }\end{array}$} & \multirow[t]{2}{*}{ Prerequisite } \\
\hline & & & $\mathrm{Lt}$ & $\mathrm{Lb}$ & & & & & $\mathrm{Lt}$ & $\mathrm{Lb}$ & \\
\hline GE 201 & Statics & 3 & 3 & 0 & PHYS 103 & ME 202 & Dynamics & 3 & 3 & 0 & GE 201 \\
\hline ME 271 & Thermodynamics I & 3 & 3 & 0 & $\begin{array}{l}\text { PHYS 103, } \\
\text { MATH } 201\end{array}$ & ME 272 & Thermodynamics II & 3 & 3 & 0 & ME 271 \\
\hline ME 231 & Materials science & 3 & 3 & 0 & CHEM 103 & ME 232 & $\begin{array}{l}\text { Mechanics of } \\
\text { materials }\end{array}$ & 4 & 3 & 3 & $\begin{array}{c}\text { GE 201, ME } \\
231\end{array}$ \\
\hline MATH 202 & Advanced calculus & 3 & 3 & 0 & MATH 201 & ME 222 & $\begin{array}{l}\text { Engineering } \\
\text { graphics }\end{array}$ & 3 & 1 & 6 & \\
\hline ENGL 214 & Technical writing & 3 & 3 & 0 & ENGL 104 & MATH 303 & $\begin{array}{l}\text { Differential } \\
\text { equations (1) }\end{array}$ & 3 & 3 & 0 & MATH 201 \\
\hline \multirow[t]{2}{*}{ ISLS 201} & Islamic culture (2) & 2 & 2 & 0 & ISLS 101 & ISLS 301 & Islamic culture (3) & 2 & 2 & 0 & ISLS 201 \\
\hline & Total & 17 & & & & & Total & 18 & & & \\
\hline
\end{tabular}

(c) Third year (junior)

\begin{tabular}{|c|c|c|c|c|c|c|c|c|c|c|c|}
\hline \multicolumn{6}{|c|}{ First semester } & \multicolumn{6}{|c|}{ Second semester } \\
\hline \multirow{2}{*}{$\begin{array}{l}\text { Code and } \\
\text { number }\end{array}$} & \multirow[t]{2}{*}{ Course title } & \multirow[t]{2}{*}{$U$} & \multicolumn{2}{|c|}{$\begin{array}{l}\text { Contact } \\
\text { Hours }\end{array}$} & \multirow[t]{2}{*}{ Prerequisite } & \multirow{2}{*}{$\begin{array}{l}\text { Code and } \\
\text { number }\end{array}$} & \multirow[t]{2}{*}{ Course title } & \multirow[t]{2}{*}{$U$} & \multicolumn{2}{|c|}{$\begin{array}{c}\text { Contact } \\
\text { Hours }\end{array}$} & \multirow[t]{2}{*}{ Prerequisite } \\
\hline & & & $\mathrm{Lt}$ & $\mathrm{Lb}$ & & & & & $\mathrm{Lt}$ & $\mathrm{Lb}$ & \\
\hline ME 371 & Fluid Mechanics I & 4 & 3 & 3 & $\begin{array}{c}\text { ME 202, } \\
\text { MATH } 303\end{array}$ & ME 352 & $\begin{array}{l}\text { Mechanical } \\
\text { Design I }\end{array}$ & 4 & 4 & 0 & ME 232 \\
\hline ME 341 & $\begin{array}{l}\text { Mechanics of } \\
\text { machines }\end{array}$ & 3 & 2 & 3 & ME 202 & ME 342 & $\begin{array}{l}\text { System Dynamics } \\
\text { and Control }\end{array}$ & 4 & 3 & 3 & $\begin{array}{l}\text { ME 202, } \\
\text { MATH } 303\end{array}$ \\
\hline ME 321 & $\begin{array}{l}\text { Manufacturing } \\
\text { process I }\end{array}$ & 3 & 3 & 0 & ME 231 & ME 372 & Heat transfer & 4 & 3 & 3 & MB 371 \\
\hline EE 301 & $\begin{array}{l}\text { Fund. of Elect } \\
\text { Engineering }\end{array}$ & 4 & 3 & 3 & PHYS 104 & ME 312 & $\begin{array}{l}\text { Instrumentation } \\
\text { and } \\
\text { Measurements }\end{array}$ & 3 & 2 & 3 & $\begin{array}{c}\text { MATH 201, } \\
\text { EE } 301\end{array}$ \\
\hline \multirow[t]{2}{*}{ MATH 315} & $\begin{array}{l}\text { Engineering } \\
\text { mathematics }\end{array}$ & 3 & 3 & 0 & MATH 303 & ST AT 301 & $\begin{array}{l}\text { Prob. and Stat. for } \\
\text { engineers }\end{array}$ & 3 & 2 & 3 & \\
\hline & Total & 17 & & & & & Total & 18 & & & \\
\hline
\end{tabular}


(d) Summer training

\begin{tabular}{|c|c|c|c|c|c|}
\hline \multirow{2}{*}{$\begin{array}{l}\text { Code and } \\
\text { number }\end{array}$} & \multirow{2}{*}{ Course title } & \multirow{2}{*}{$U$} & \multicolumn{2}{|c|}{ Contact hours } & \multirow{2}{*}{ Prerequisite } \\
\hline & & & Lt & $\mathrm{Lb}$ & \\
\hline \multirow[t]{2}{*}{ ME 390} & $\begin{array}{l}\text { Professional training in } \\
\text { mechanical Engineering }\end{array}$ & 0 & 0 & 0 & ENGL 214, junior standing (completed a minum 85 credit units) \\
\hline & total & $\mathbf{0}$ & $\mathbf{0}$ & $\mathbf{0}$ & \\
\hline
\end{tabular}

(e) Fourth year (senior)

\begin{tabular}{|c|c|c|c|c|c|c|c|c|c|c|c|}
\hline \multicolumn{6}{|c|}{ First semester } & \multicolumn{6}{|c|}{ Second semester } \\
\hline \multirow{3}{*}{$\begin{array}{l}\text { Code and } \\
\text { number }\end{array}$} & \multirow{3}{*}{ Course title } & \multirow{3}{*}{$U$} & \multirow{2}{*}{\multicolumn{2}{|c|}{$\begin{array}{l}\text { Contact } \\
\text { Hours }\end{array}$}} & \multirow{3}{*}{ Prerequisite } & \multirow{3}{*}{$\begin{array}{l}\text { Code and } \\
\text { number }\end{array}$} & \multirow{3}{*}{ Course title } & \multirow{3}{*}{$U$} & \multirow{2}{*}{\multicolumn{2}{|c|}{$\begin{array}{l}\text { Contact } \\
\text { Hours }\end{array}$}} & \multirow{3}{*}{ Prerequisite } \\
\hline & & & & & & & & & & & \\
\hline & & & Lt & $\mathrm{Lb}$ & & & & & Lt & $\mathrm{Lb}$ & \\
\hline ME 491 & $\begin{array}{l}\text { Capstone Design } \\
\text { Project I }\end{array}$ & 1 & 1 & 0 & $\begin{array}{c}\text { ME 352, ME } \\
372\end{array}$ & ME 492 & $\begin{array}{l}\text { Capstone Design } \\
\text { Project II }\end{array}$ & 3 & 1 & 6 & ME 491 \\
\hline ME 451 & Mechanical design II & 3 & 2 & 3 & ME 352 & ME 452 & $\begin{array}{l}\text { Finite element } \\
\text { analysis }\end{array}$ & 3 & 3 & 1 & ME 232 \\
\hline ME 4xx & Technical elective & 3 & 3 & 0 & & ME $4 x x$ & Technical elective & 3 & 3 & 0 & \\
\hline ME $4 \mathrm{xx}$ & Technical elective & 3 & 3 & 0 & & $\mathrm{XX} \mathrm{xxx}$ & Technical elective & 3 & 3 & 0 & \\
\hline GE 405 & $\begin{array}{l}\text { Engineering } \\
\text { economy }\end{array}$ & 2 & 2 & 0 & & GE 406 & $\begin{array}{l}\text { Engineering } \\
\text { management }\end{array}$ & 2 & 2 & 0 & \\
\hline \multirow[t]{2}{*}{ ARAB 201} & Arabic language (2) & 3 & 3 & 0 & ARAB 101 & ISLS 401 & Islamic culture (4) & 2 & 2 & 0 & ISLS 301 \\
\hline & Total & 15 & & & & & Total & 16 & & & \\
\hline
\end{tabular}

Total credits required in the degree program: 136.

TABLE 3: Relation between the course objectives and ABET learning outcomes.

\begin{tabular}{|c|c|c|c|c|c|c|c|c|c|c|c|}
\hline \multirow{2}{*}{ Objective } & \multicolumn{11}{|c|}{ Outcome } \\
\hline & $\mathrm{a}$ & $\mathrm{b}$ & c & $\mathrm{d}$ & $\mathrm{e}$ & $\mathrm{f}$ & $\mathrm{g}$ & $\mathrm{h}$ & $\mathrm{i}$ & j & $\mathrm{k}$ \\
\hline 1 & $\mathrm{x}$ & & & & & & & & & & \\
\hline 2 & & & & & $\mathrm{x}$ & & & & & & \\
\hline 3 & & $\mathrm{x}$ & $\mathrm{x}$ & & & & & & & & \\
\hline 4 & & & & $\mathrm{x}$ & & & & & & & \\
\hline 5 & & & & & & & $\mathrm{x}$ & & & & \\
\hline 6 & & & & & & $\mathrm{x}$ & & $\mathrm{x}$ & & $\mathrm{x}$ & \\
\hline
\end{tabular}

themselves in the learning process and become independent inquirers. Using problems or cases from real life in teaching is effective for motivating students and enhancing their learning and development of skills. Students need to learn how to get the information when needed, as this is an essential skill for professional performance.

In the project based approach, the students need to produce a viable design solution to solve an open-ended problem and they are required to produce an outcome in the form of a report guided by the facilitators. The learning process is directed by teaching and focuses on the application and assimilation of previously acquired knowledge. This approach prepares engineering students to "practice engineering" by applying their knowledge to solve the design problems and provide a real outcome for evaluation. Also, this approach enhances the student's self-directed study skills and it becomes a student's responsibility.

The design based learning approach is self-directed process in which students initiate learning by designing creative and innovative practical solutions which fulfill customer expectations. Design based learning is an effective vehicle for learning that is centered on a design problem solving structure. Integrating design and technology tools into science education provide students with dynamic learning opportunities to actively investigate and construct innovative design solutions. This approach provides the students with essential skills as hands-on work, problem solving, collaborative teamwork, innovative creative designs, active learning, and engagement with real-world assignments. More details on the proposed capstone project will be clarified in the following section.

\subsection{Project Information}

(i) The best source for an open-ended design problem suitable for the capstone project is collaboration with local industry, local community organization, and research facilities [12-15, 23-27]. University sponsored projects could be used in developing needed lab equipment or sponsoring national and international design competition teams. Also, the students are given the opportunity to propose their own design ideas. In the proposed course, the university was sponsoring the teams to develop a concept vehicle powered with renewable energy source with the goal to fulfill national mission.

(ii) The number of students per capstone teams varied in several studies $[10,11,39]$. In this course implementation it was found that teams from 3 to 4 students gave the best results. 
(iii) The student has to successfully pass the first course in order to enroll in the second course.

(iv) In order to motivate the students' leadership and build accountability within the team, students are organized to have a team leader, secretary, treasures, and web master.

(v) The ME program under consideration is a general program. Students can elect to have more in-depth knowledge in one of the ME tracks through the elective courses. The department tracks include thermal and fluid sciences, design and manufacturing, materials and solid mechanics, and dynamic systems and control. Students can also choose a capstone project related to their preferred track to strengthen their ability to apply his knowledge into the real-life problem. Also, integration with teams from other departments could enhance the interdisciplinary team work.

\subsection{Phases in Capstone Projects}

(a) Project identification: the proposed design problems are submitted to a committee that reviews the design contents and visibility of offering it as a capstone project. This step should be completed before the semester starts.

(b) Orientation seminar: the candidate students are invited to orientation seminar before the end of the previous semester. Brief information on the course, the course implementation, team selection and assignment process, policies and procedures, and deliverables are presented.

(c) The projects and the design problems are announced to the students in the 1st week of the semester.

(d) Initial assignment of the student teams is announced at the same time. Different approaches have been used to place the students in teams. Each one of those approaches could be considered a simulation to situation that could happen in the real industrial organization as follows.

(i) The students are given a chance to pick their own teammates along with the project. This simulates a situation when students with the same interest come up with an idea and they want to execute it. This approach emphasizes the leadership and entrepreneurship competencies in the students.

(ii) The project is assigned to the students team to execute it. This situation simulate a situation in a company where different members from different department (may be with different interests and backgrounds) are assigned to work on the project. This scenario will improve the students' team work and communication skills. (iii) The students are distributed on the projects based on their GPA such that a balanced distribution is maintained among the projects. This scenario motivates and enhances the students learning process and improves the overall quality of the project deliverables.

In all cases, students are given a chance to change their teams.

(e) Proposal phase is as follows.

(i) Once the students receive their design problem and the team assignment, they start gathering information, investigating the design problem, clarifying the client needs, and developing the problem statement.

(ii) The team conducts initial search to clarify and sharpen their design problem statement. This stage is marked with extensive meetings with the client and frequent meetings with the team adviser.

(iii) In third week, each team is required to conduct preproposal presentation before a technical committee and the client. This presentation ensures that the client problem is addressed and the technical aspects are covered. Feedback from the committee enhances the students proposal and sharpens their understanding of the design problem.

(iv) In the fourth week, the students are required to submit the final proposal to the course coordinator who will communicate with the client to get their feedback and approval. The proposal must include background materials, objectives, a technical approach, a budget, a schedule with milestones, and a list of deliverables.

(v) The list of deliverables is used as a checklist at the end of the year as the first requirement for a grade in the course.

(vi) As a result, the client, faculty, and students must sign off on the proposal before design work can begin.

(f) Design alternatives and solution analysis: once the proposal is approved, the students start to undertake the design tasks.

(i) Exhaustive search: students perform exhaustive search on the assigned design problem, gather more information on the customer requirements and needs, and look for the available solutions in the market or the literatures.

(ii) At this stage, the students should have collected enough information to define in detail their tasks and submit a detailed Gantt chart for their project plan that spans the two semesters.

(iii) Alternative solutions and idea generation: students must generate different viable alternative solutions for their problem. A viable alternative is a solution that could perform the required tasks, deliver the expected output, or achieve the desired goals. 
(iv) Performance criteria: after this exercise, the team should have gathered enough information about their designs alternatives along with the customer requirements to identify the performance and selection criteria. At this stage the students should be able to develop the product specifications for the design problem.

(v) Alternative validation and analysis: the team should perform a preliminary analysis of the proposed alternatives based on the identified design performance criteria and establish the QFD.

(vi) Solution selection: based on this analysis, the student should identify the selected solution.

(g) Presentation and reporting: the students are required to prepare a final report for their activities and conduct a presentation before the client and the technical committee. The team should present their approach, design alternatives, QFD, and the final selected design solution. The committee and the client can approve the findings of the team and the team can continue their design. This activity should be completed before the end of the first semester.

(h) In the detailed design analysis process students should conduct detailed analysis of their proposed design with all the required simulations. In the meantime, the team should be able to identify the major components of their design and conduct a tradeoff between buying their components and manufacturing them. Also, they should be able to survey the market to identify the potential suppliers. Once the detailed analysis is completed, students should prepare detailed drawing for the components that will be manufactured and perform the necessary iterations for the design optimization.

(i) At this point, students are required to submit a progress report and conduct an oral presentation before the client and the technical committee.

(j) Once the presentation is completed and the design is approved, students will be able to order their components and start manufacturing.

(k) The next stage involves prototyping and testing the proposed design. The performance of the prototype is thoroughly checked against the proposed product specifications.

(1) To conclude the course, the students prepare their final report and conduct their final presentation before the client and technical committee. The coordinator checks off all the deliverables and client signs off the design.

(m) The students should maintain an up-to-date logbook and portfolio during the two courses. course contains one lecture to teach the students the new design concepts and techniques. The lecture is conducted by the appointed course coordinator. The course coordinator should have industrial experience and diverse knowledge of the different engineering disciplines. The coordinator's role is vital for the success of the capstone project. The coordinator major activities could be summarized as follows.

(i) Act as a liaison between the department and the clients.

(ii) Coordinate the project selection and student allocation in teams.

(iii) Conduct the capstone orientation seminar and deliver the course lectures.

(iv) Coordinate the capstone project activities and maintain the deadlines.

(v) Check the logbook and portfolio monthly.

(vi) Participate in the project evaluation.

(vii) Guide the students learning process and manage the teams.

The coordinator has significant challenges in his role. Based on the team assignment approach the coordinator should monitor the teams' dynamics and interfere whenever necessary. Some of the challenges that coordinator might face include the following.

(i) Creating a positive atmosphere of encouragement, motivation, teamwork, and professional/ethical responsibility.

(ii) Coaching students on how to build trust between the team members.

(iii) Helping teams trough conflicts.

(iv) Empowering the students' creativity and innovation.

4.4. Faculty Involvement. The faculty members are considered as technical advisors in this course. The faculty advising could be done through one of the following two scenarios.

(i) One faculty member advice a team: the team could meet with their advisor weekly to consult him in technical issues and seek advice.

(ii) Advisory committee is advising teams: the committee consists of faculty members from the different disciplines and background. Each team presents their progress to the committee members in a weekly meeting seeking their advices on the technical issues. The diverse expertise enriches the students learning.

4.5. Grading. The students go through a series of reporting and presentation activities to insure that the deliverable are completed on time and enforce continuity of the work, as shown in Table 4. Grading of some progress activities is assigned to the course coordinator based on his position to work closely with the students. An examining technical committee is responsible for grading the team work and 
TABle 4: Proposed schedule for assessment and grading.

\begin{tabular}{|c|c|c|c|}
\hline \multicolumn{4}{|c|}{ First semester: } \\
\hline $\begin{array}{l}\text { Project proposal/proposal } \\
\text { presentation }\end{array}$ & $10 \%$ & W5 & Coordinator \\
\hline $\begin{array}{l}\text { Log-book and portfolio } \\
\text { (monthly checked) }\end{array}$ & $10 \%$ & Monthly & Coordinator \\
\hline Project plans (GANTT) & $10 \%$ & W8 & Coordinator \\
\hline $\begin{array}{l}\text { Development of design } \\
\text { specifications and QFD }\end{array}$ & $10 \%$ & W10 & Coordinator \\
\hline Progress report-1 & $20 \%$ & W13 & Committee \\
\hline Presentation-1 & $20 \%$ & W14 & Committee \\
\hline Final exam-1 & $20 \%$ & Smstr End & Coordinator \\
\hline \multicolumn{4}{|c|}{ Second semester: } \\
\hline Progress report- 2 & $10 \%$ & W5 & Committee \\
\hline Presentation-2 & $10 \%$ & W6 & Committee \\
\hline Project log-book and portfolio & $10 \%$ & Monthly & Coordinator \\
\hline Final report & $20 \%$ & W14 & Committee \\
\hline Final presentation & $20 \%$ & W15 & Committee \\
\hline Completion of design project & $30 \%$ & W16 & Coordinator \\
\hline
\end{tabular}

deliverables. The examining committee may include a representative of the client or the project sponsor, the coordinator, and an examiner with good technical background of the project subjects.

\section{Virtual Product Development in Different Phases}

In [17], Sanschagrin et al. presented an implementation of the VPD as an option during the last year of the mechanical engineering curriculum. As commented by the author, VPD provide a realistic environment that supports the modification of an existing design and its analysis. In the meantime, VPD represented an environment presenting the future engineer's work.

Virtual product development refers to the tools and procedures used in product development during the different phases. VPD enables companies to leverage the available resources by optimizing their product designs leading to improved performance, reduced physical prototypes, verifiable quality improvements, and minimized operational problems and failures. VPD procedures are implemented through all the product design phases starting from the concept realization and ideation, solution and alternative generation, performance evaluation, progressing towards the final design and analysis, and ending with prototyping and launching. VPD encompasses tools for integrating the contribution from the individual team members, integrating different subsystems from the different disciplines, enabling multidisciplinary teams/simulation, and utilizing the performance and simulation results as feedback to improve or approve product design. VPD tools reduce the cost of product evolution through the different product generation.

The core of the VPD process is the capability to generate CAD models, use simulation software to represent physical environments and events in evaluating the operability of a product design, compare the simulation results to physical test results, and optimize the product design to meet the client needs. Different products will definitely require different set of tools and may require alternating the sequence of implementation based on the component physics and product type. Some products may require FEA analysis, CFD, heat transfer, electronics and controls, and so forth.

5.1. Requirements of Integrated VPD Environment. For mechanical engineers, computer aided drawing (CAD) module is the heart of the VPD environment that enables the student engineers to convert their ideas into drawings or sketches that could be communicated with other team members, other teams, and the client. The CAD design tools have the following impacts:

(i) Provide the capability for model generation and manipulation, design collaboration and integration, and data exchange.

(ii) For many organizations, the VPD processes must be tightly integrated with the CAD processes implemented in the design stages.

VPD procedures should integrate the CAD system in the following phases:

(i) space allocation for the different subsystems,

(ii) generation of assemblies and part geometry,

(iii) part detailing and dimensioning,

(iv) product design data,

(v) functionality and interference check.

The assemblies generated from CAD process are the building blocks for the simulation model. The CAD package exports the model into the appropriate analysis tools. The analysis tools could be used to answer vital questions: how much tension, compression, bending, twisting, or vibration does a product endure? How hot or cold does a structure get? Does the materials change over time as they become hotter, colder, or they deform? What is the power generated or required for the system?

VPD procedures integrate the analysis tools for the following cases:

(i) kinematic and dynamic simulation of mechanisms motion to predict the ability of the system to achieve the functions, determine the reaction forces, and estimate the required/produced power;

(ii) fluid flow and fluid structure interaction predicting the flow properties and performance of the design or conditions, power generation, drag forces, structural induced loads, and so forth;

(iii) thermal and heat transfer and heat generation during operation;

(iv) interaction with environment under different working conditions which should be accounted for in the simulation software through the appropriate loads and boundary conditions; 
(v) finite element analysis to predict the response of the model under applied loads;

(vi) electromechanical systems and controls simulations.

Seamless interfacing between CAD environment and the analysis tools is an essential link in the VPD process. Product optimization and design iterations require interoperability between CAD and the VPD analysis tools.

5.2. Benefits of Using VPD in Capstone Design Project. In [17], Sanschagrin et al. reported that the students positively commented on how a complex project could be realized using VPD. Also, VPD urged students to return to some of the concepts and theories they have learnt in various courses during the curriculum and they were able to utilize these concepts to make decisions and reach the technical goal. In this course, the implementation of VPD has the following benefits.

(i) Acquaint the student engineers with the necessary fundamental concepts to join the job market. Specific VPD procedures and tools may vary between companies based on the product line and the companies established policies and procedures.

(ii) Reduce the number of design iterations during the design phase.

(iii) Allow the students to perform more design analysis and conduct comprehensive design of experiments.

(iv) Provide a rich platform for collaboration between teams working on the subsystems and close collaboration between multidisciplinary teams.

(v) Reduce the time and effort to finish the students assignments. Students can generate scripts to automate design/analysis scenarios.

(vi) Improve the students understanding of their design problem and allow them to perform more complicated analysis tasks.

(vii) Improve the communication between team members and with the client.

(viii) Enhance the quality of students' presentation.

5.3. Phases of Using VPD in the Capstone Project. Section 4 presented a detailed list of the activities associated with the course. However, the activities related to design project could be divided into three major phases, as shown in Figure 1: design problem and alternatives generation, detailed design and analysis, and finally prototyping and testing. VPD tools could be identified to help the students during each phase and the procedures could be aligned with all the activities of the capstone design project.

Identifying the proper VPD tools for capstone is a major challenge in itself. There is a debate between adopting and adapting open-source tools versus commercially available packages. This issue will not be addressed here but commercial package will be most suitable to achieve the course goals. Currently, there are different commercial packages that offer integrated product development environment, while, in the meantime, team collaboration and model management capabilities are integrated. The following is a list of example packages with capabilities ranging from CAD only to fully integrated development platform: AutoCAD, PTC Suit, Dassault Systèmes (SolidWorks), CATIA, Ansys Workbench, Altair HyperWorks, Recurdyn, MSC Software, and Siemens NX. The VPD tool requirements could be summarized for the different phases of the design process as follows.

(i) Phase I: design problem and conceptualization.

(a) Understanding the design problem and gathering information.

(b) Searching through similar solutions.

(c) Retrieving data/information from existing designs and products (data/information could be archived electronically within the development environment).

(d) Generating new design solution alternatives:

(1) Capturing ideas suing electronic tools: sketching, 2D and 3D CAD tools, and rendering tools.

(2) Exchanging ideas between different teams using centralized data management system.

(e) Defining the product design and performance specifications. The specifications will be shared between all the teams.

(f) Performing preliminary design analysis of the different alternatives.

(1) Customer and client surveys and identifying the critical customer requirements.

(2) Build simplified mathematical model for each alternative to analyze performance.

(3) Simple 2D models, linearized models, empirical behavioral relations, standalone subsystem analysis, and steady state analyses could be sufficient at this stage.

(4) Performing QFD and identify the proposed design solution for the design problem.

(ii) Phase II: After identifying/deciding the design solution, detailed analysis and CAD models need to be developed.

(a) One of the most critical steps in this phase is to identify the subsystems.

(1) Define the design space for each subsystem and an owner.

(2) Define policies for subsystem integration and a design integration management system.

(3) Defining the deadlines to finalize subsystem design and integration and setting the design-freeze dates.

(b) Generate detailed CAD for the design subsystem components and parts. 


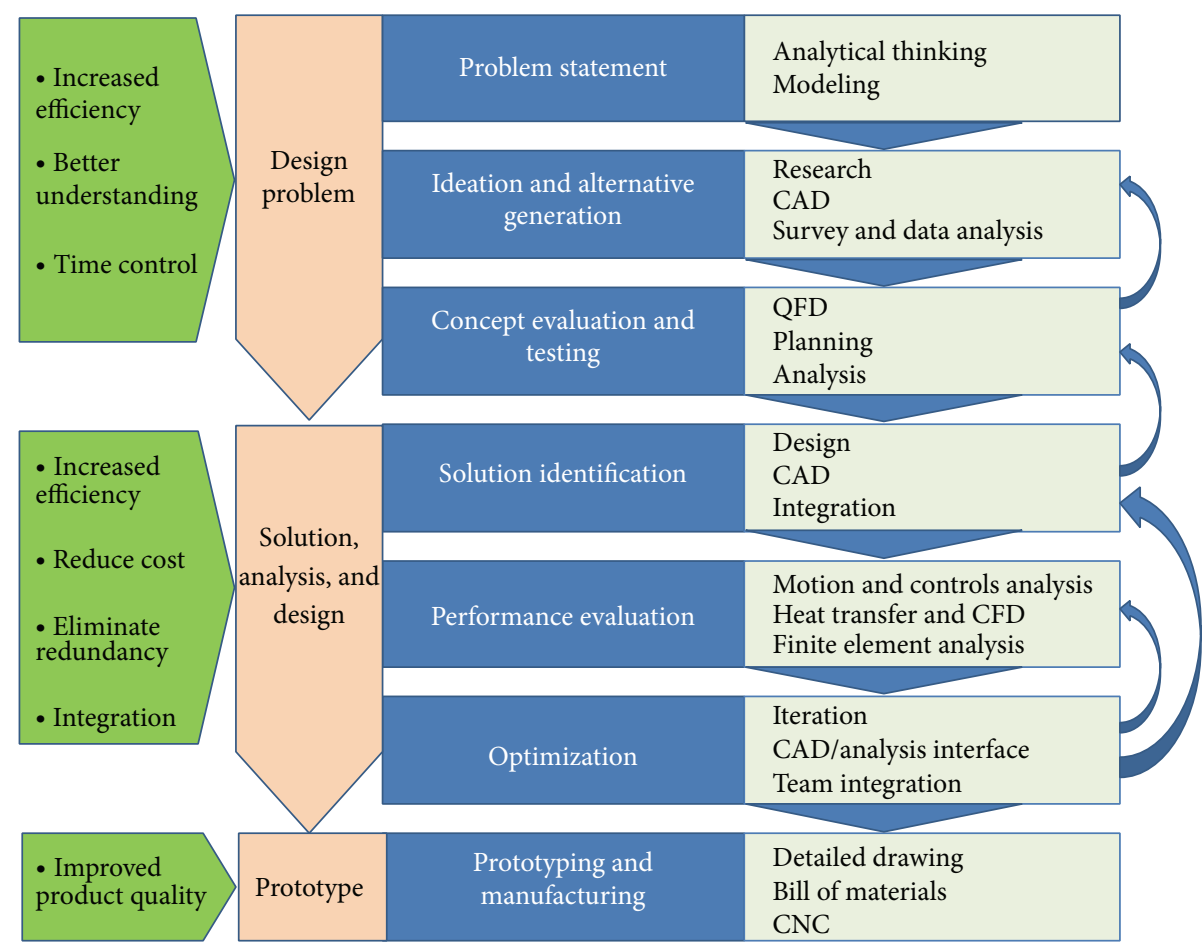

FIGURE 1: Design process and VPD activities.

(c) Export the subsystem for detailed analysis. The VPD development environment could have built-in analysis capability and the analysis could be performed with the same workspace. The detailed analysis depends on the subsystem and required performance criteria. Finite element analysis could be performed for structural components, critical speed analysis for rotating machinery, turbulent flow analysis for wind turbines, efficiency of solar energy collection system, and so forth. In more advanced simulations, different subsystems could be modeled together in metaphysics simulation program like fluid-structure interaction, coupled current flow and heat generation in a conductor, and so forth.

(d) The analysis may require multiple phases: motion analysis to determine the inertia and reaction forces followed by structural analysis to determine the stresses distribution in specific component.

(e) Results from the analysis could be used to change the part/component design or the subsystem configuration and reanalysis will be necessary at this stage.

(f) Reiteration may be required to optimize the component behavior. The CAD system could be integrated with the analysis tool during the optimization or the process could be automated through scripts to reduce the time. (g) At this stage, the subsystems need to be integrated under collaboration/design management tool. The overall performance of the solution could be analyzed. Changes in the subsystems could be suggested based on this analysis results.

(h) Detailed reports could be generated from the VPD environment and analysis tools.

(iii) Phase III: once the detailed analysis of the design solution is completed, detailed drawing for each part or component could be generated from the CAD system:

(a) detailed dimensions and tolerances for each part;

(b) detailed bill of material could be generated;

(c) parts and components could be manufactured by communicating the $\mathrm{CAD}$ drawing to $\mathrm{CNC}$ machines or $3 \mathrm{D}$ printing machines.

(iv) The detailed design and analyses results could be communicated with client and archived for future development.

\section{Challenges in Implementing Integrated VPD System in the Capstone Course}

The nature and requirements of every capstone project are different because the proposed design problems are different. As a consequence, the design approach to solve the 
design problem might be different. Since the coordinator is responsible for the class management, his/her unique talent with diverse experience and leadership qualities may be a determining factor in the success of the capstone project course and the proper VPD implementation.

6.1. Managing/Guiding the Learning Process. Two aspects need to be taken into account to insure the course success: managing the student learning process and managing the procedure to solve the design problem. Managing/guiding the learning process involves two components: teaching the fundamental course subjects and applying them in the capstone project and teaching the specific topics of the project problem. The coordinator manages teaching class topics through the following.

(i) Managing the learning contents in the different projects.

(ii) Identifying the proper VPD tools for each design problem.

(iii) Lack of students' experience with VPD tools requires teaching the necessary software and tools: run-tolearn approach will be most effective in this case.

(iv) Helping the students in the implementation to their specific design problem.

(v) Encoding the professional engineering ethics as part of the course practice and strategy. Also, locally available professional code of ethics must be included as part of the course policies.

6.2. Team Management. Another very important challenge for the course coordinator is managing the different teams with their diverse needs. The following are among the challenges that might face coordinator.

(i) Team selection and project assignment based on the predefined class policy.

(ii) Clarifying tasks and objectives for the different teams.

(iii) Coaching the teams with team values and team success factors:

(a) encouraging individual initiatives,

(b) developing an atmosphere of shared accountability,

(c) building trust among the team members and among different teams.

(iv) Team encouragement, coordination, and empowering for high performance teams:

(a) commitment to the project plan, deliverable, and milestones;

(b) dealing with conflicts between the individual team members;

(c) dealing with conflicts between teams working on subsystems; (d) enforcing important deadlines like designfreeze;

(e) managing the multidisciplinary integration meetings and resolving design conflicts;

(f) managing shared resources;

(v) teaching students how to manage project budget and resources.

\section{Students Learning Assessment}

The overall capstone project assessment includes four categories encompassing the different phases of the project evolution as follows.

(1) Requirement and planning: assessing the student ability to identify the customer needs, the problem formulation, project proposal, and project plan.

(2) Conceptualization and assessment: the ability to identify the critical customer requirements, generating different feasible design alternative, quantify performance of different alternatives, and define the product specifications.

(3) Design and analysis: utilizing the VPD tools to perform comprehensive modeling and analysis, communicating design with other teams, and generating manufacturing-ready detailed engineering drawing.

(4) Prototype and delivery: assessing the ability to use standards and codes, identifying suppliers, purchasing, realizing a model through different prototyping techniques, and performing comprehensive model testing under different conditions.

In order to ensure the students steady and continuous progress, a series of reporting activities evolve during the two semesters. An example of reporting and progress assessment schedule is shown in Table 4 . The performance assessment must include two parts: the team performance assessment and the individual contributions assessment. Most of the reporting and prototyping activities are considered team work, while a few activities can distinguish the individuals' capabilities such as the presentations and the exams. Good performance in the presentation does not imply that the team member have had significant contributions to the group deliverables [43]. This mandates that the team member's contributions to the group activities should be assessed separately. In this proposed course, individual contribution is quantified by asking each student team member to evaluate the performance of the other team members. Also, the project faculty advisor/coordinator is asked to evaluate each individual's performance. The average of those two evaluations indices is used to calculate the contribution factor for each team member.

\section{Case Study: Taibah University Solar Car}

The proposed course structure and procedures were implemented over two consecutive years in mechanical engineering program. The goal was to design and build a solar 
powered car with the target to participate in international solar car competitions. The project was entirely funded by the university.

In the first year, four individual interdisciplinary projects were offered to mechanical and electrical engineering students to build the solar car. The ME students were assigned into three projects as follows: team 1 was responsible for the shell and structure, team 2 was responsible for the drive train and rear suspension system, and team 3 was responsible for the front suspension system, steering system, and driver cockpit. The EE team was responsible for the power collection and the controls.

In the second year, the four individual projects were offered to mechanical engineering students to build a modified version of the solar car based on the experience gained from the first year. The students were assigned into four projects as follows: team 1 was responsible for the shell and structure, team 2 was responsible for the drive train and rear suspension system, team 3 was responsible for the front suspension system, steering system, and driver cockpit, and team 4 was responsible for the solar power collection, power storage, and the controls.

A general design problem was given to all teams to define the solar car major specifications and requirements according to the international competitions guidelines. A specific design problem was given to each team to define the subsystems. Each team identified the major components in their subsystems, the design requirements, and the required major analyses as follows.

(i) Shell and structures team:

(a) the shell needs to be light weight and optimized for aerodynamic performance; this requires airfoil selection, aerodynamic simulation using CFD, finite element analysis of the shell under the distributed pressure, and inertial and gravitational loads;

(b) the supporting structure needs to be sufficiently stiff to support the car loads during the driving course and at the same time have minimum weight; finite element analysis needs to be performed based on the different loading boundary conditions; the loads include the gravitational and inertial loads and the reaction forces at the connections to the subsystems.

(ii) Suspension, steering, and cockpit team:

(a) steering system: achieve the minimum steering radius with minimum weight; analysis includes mechanism analysis of the full vehicle system;

(b) cockpit: dimensions can accommodate the human driver with clear and adequate visibility of the surrounding objects, provide sufficient protection to the driver, and facilitates the driver entrance and exit; the analysis includes generating a digital model for the driver, performing finite element analysis to ensure driver protection, and performing visibility assessment for the driver;

(c) suspension: support the car weight and provide sufficient traction force; analysis includes mechanism analysis of the full vehicle system and extracting the reaction forces for the structural analysis.

(iii) Drive train and rear suspension team:

(a) the drive train includes a DC motor, sprockets and chains, and rear suspension mechanism; the subsystem is required to convert the stored electric power into mechanical power with maximum efficiency at different speeds; the team needs to decide whether to use a front wheel drive or rear wheel drive system and select the necessary components; the team will need to perform the full mechanism analysis and extract the loads and reaction forces that will be transmitted to the structure; students will need to design the controllers that will deliver the power necessary to drive the car within the limits of the stored power in the batteries;

(b) perform cosimulation of the controls and the DC motor and the mechanism.

(iv) Power collection storage and controls team:

(a) energy collection and storage: the objective is to collect power from the sun using solar panels to sufficiently power the solar car; the excess collected power needs to be stored into highperformance batteries to be used when needed; charge controller needs to be designed to synchronize the charge and discharge cycle;

(b) power controller for the DC motor and the lights to enable driving the DC motor at different speeds; as per regulations, the solar car needs to be equipped with head lights and turning lights.

Student teams were able to follow the class procedures and practice using the VPD tools and procedures. The CAD software was considered the heart of all the projects. Every team designated a team member to control the CAD model of their subsystem. A student was designated as the project design controller who is responsible to the system integration and merging the subsystems CAD models. The following list summarizes the achievements of each team.

(i) Shell and structures team:

(a) performed drag and lift analysis on the different airfoils to determine the most suitable airfoil for the shell shape; 


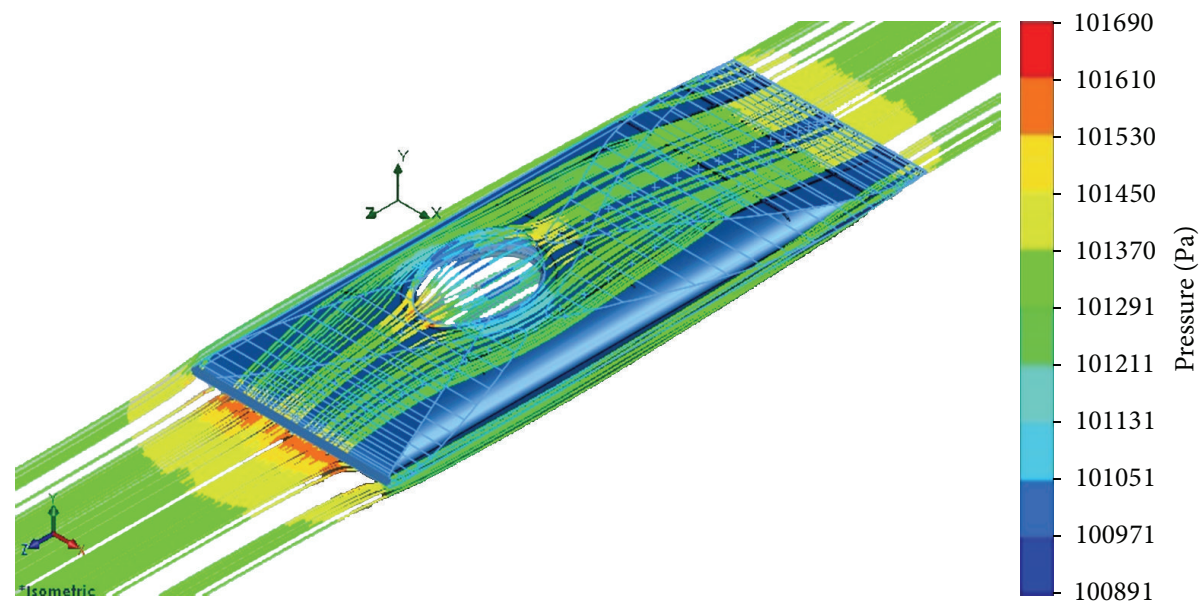

FIGURE 2: CFD analysis of the air flow around the selected shell.

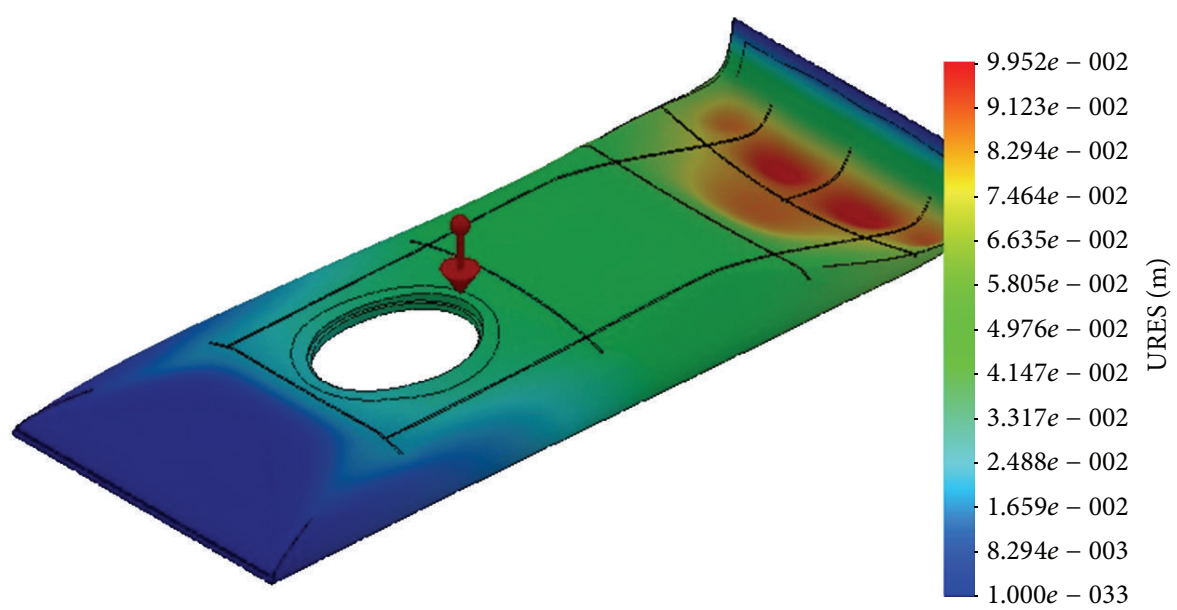

FIGURE 3: FEA analysis of the shell under aerodynamic loads.

(b) the shell model was generated using CAD software and the geometry was used to assess the drag and lift forces, as shown in Figure 2;

(c) the cockpit cover was imported from Team 2 and included in the detailed CFD analysis, as shown in Figure 2;

(d) the structural analysis of the shell under the effect of aerodynamic pressure and the gravitational load were performed using composite material properties, as shown in Figure 3;

(e) different configurations for the structure were generated and analyzed to select the minimum weight alternative;

(f) finite element analysis was performed under the effect of the static loads; dynamic loads were shared from Team 2 and team 3 from the mechanism analysis; the induced stresses were compared to the failure stresses; the structural deformation was carefully assessed to ensure the structural and functional integrity, as shown in Figure 4.

(ii) Suspension, steering, and cockpit team:

(a) Team 2 generated different design concepts in the CAD software package;

(b) the relative motion of different components in the suspension and steering system was examined using kinematic motion to ensure that the design is adequate;

(c) a preliminary design for the structure and rear suspension system was integrated and assembled to ensure compatibility between the subsystems;

(d) the assembly was exported to mechanism analysis software to analyze the vehicle motion and 


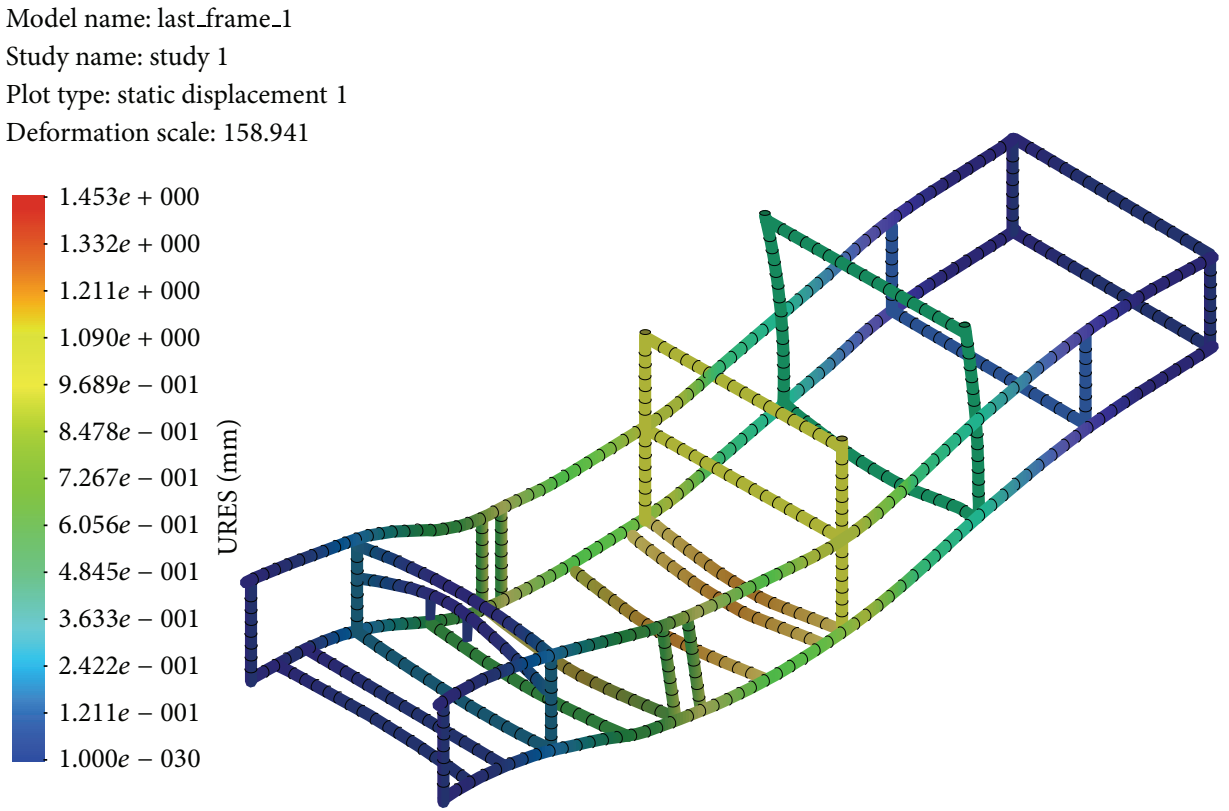

FIGURE 4: FEA analysis of the proposed structure under gravitational loads.

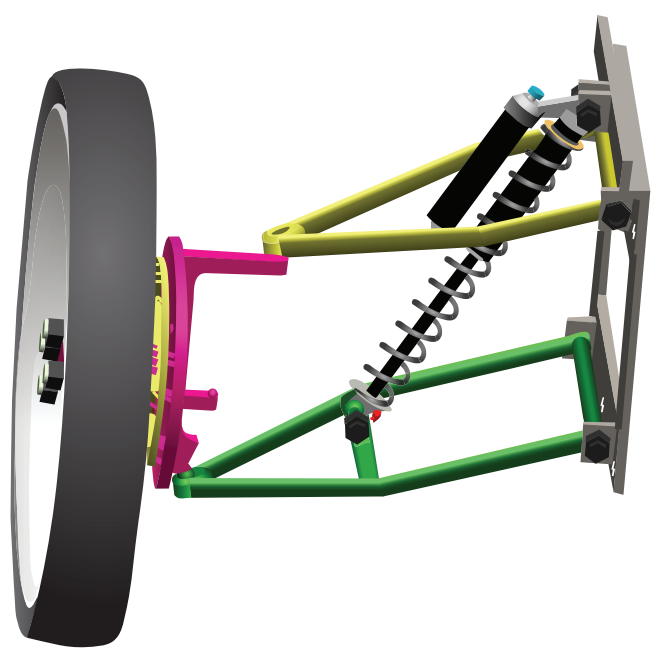

FIGURE 5: Assembly of the front suspension system.

determine the reaction forces during the course of different motion scenarios;

(e) final design and assembly for the front suspension system and steering system have been generated as shown in Figure 5;

(f) the students identified one member to be the driver; a digital model with exact dimensions for the driver was generated;

(g) the digital driver model was used to define the cockpit dimensions, the position of the pedals, the location and size of the steering wheel, and the layout of the dashpot and internal controls. (iii) Drive train and rear suspension team:

(a) preliminary calculation of the vehicle power could be calculated based on the design speed, drag forces, and the required acceleration;

(b) different design alternatives for the subsystem could be generated using the CAD software and could be tested for the motion envelope;

(c) based on the required power, the motor, drive chain, sprockets, and braking system could be designed and selected;

(d) the CAD model and preliminary components from Teams 1 and 2 could be used to generate a simplified assembly which could be exported to the motion/mechanism analysis software; 
Model name: ARMANDPLATE

Study name: study 1

Plot type: static nodal stress 1

Deformation scale: 21.7229
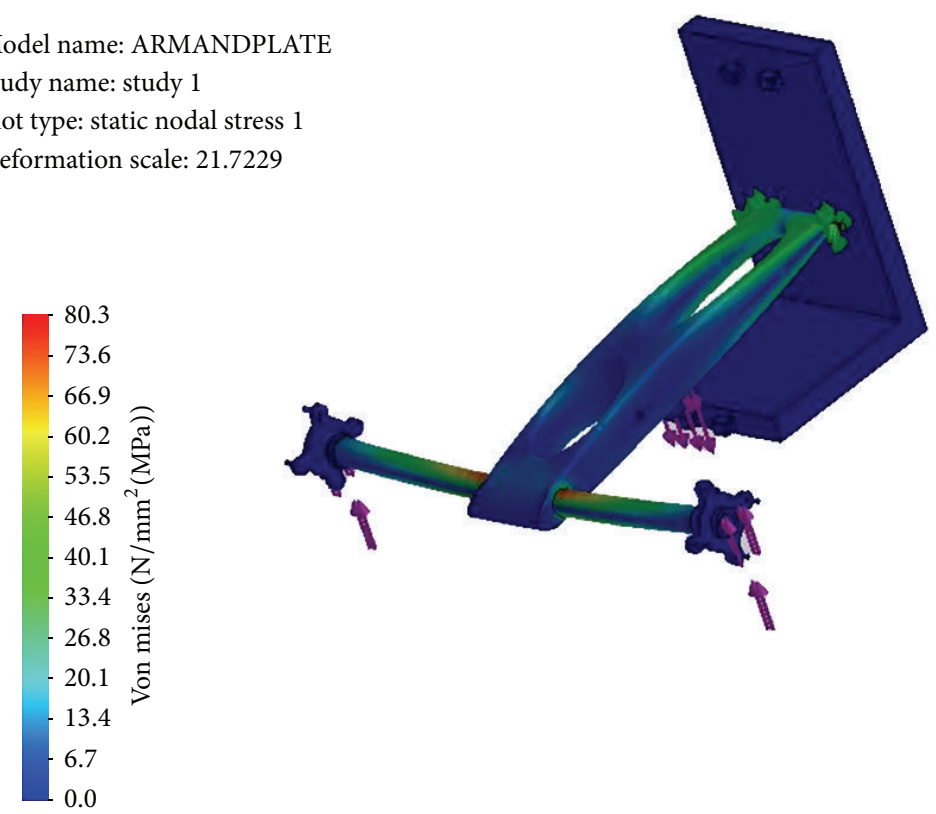

FIGURE 6: Finite element analysis of the rear suspension system.

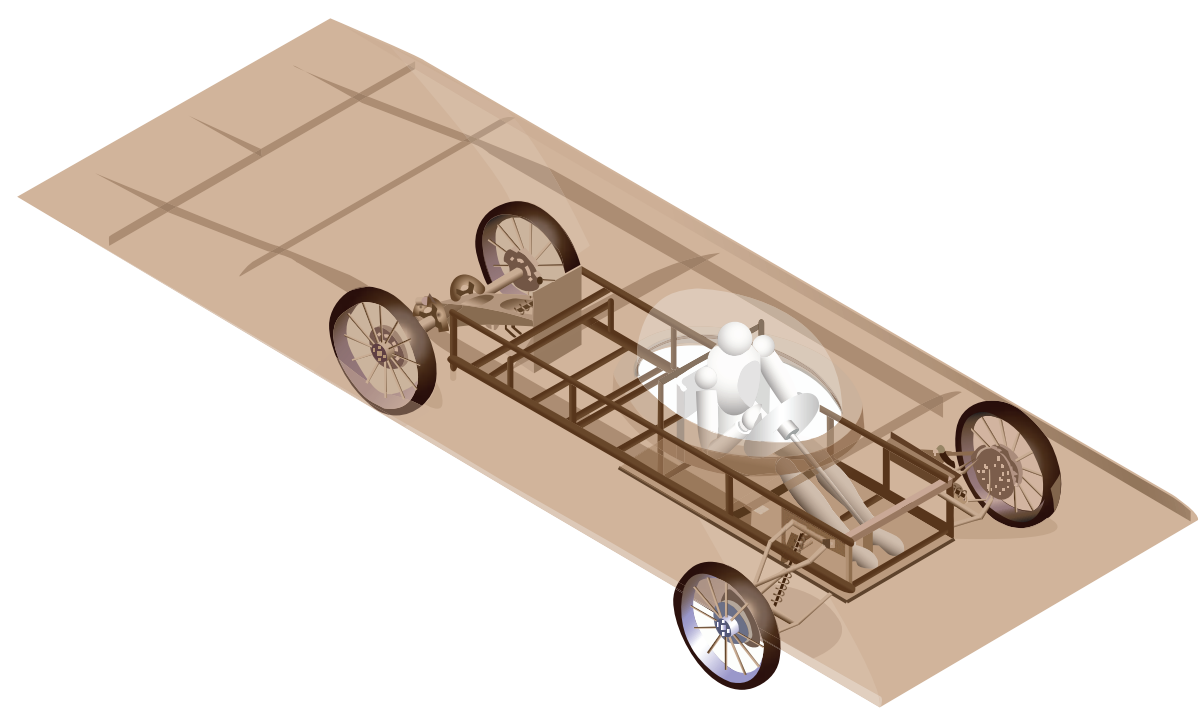

Figure 7: Final design assembly with the driver and the shell.

(e) a simplified model for the motor is modeled as an electric component in the controls software and the output torque is communicated to the mechanism analysis software for cosimulation;

(f) full mechanism analysis could be performed and the reaction force could be recorded for FEA analysis, as shown in Figure 6.

(iv) Power collection storage and controls team:

(a) the students need to identify the most economic option for solar panels that will generate sufficient power; (b) the students use the CAD model of the shell to determine the distribution of the panels on the shell surface and maximize the surface area coverage. Solar cell panels' characteristics could be communicated to the shell design team to study the effect of the surface roughness on the drag force;

(c) students should select the batteries with best performance and select a charge controller; weight and location of the batteries should be communicated with the structure design team to include it in their analysis; 
(d) a controller for the DC motor should be designed and the performance of the control system is analyzed using control system analysis software.

Integration team meetings were scheduled every two weeks where the allocated design space was checked and the integrity of the system was assessed. After completing the subsystems, the design controller assembles the individual subsystems and tries to resolve conflicts. If significant changes were required, some analyses may need to be repeated. Figure 7 shows the design assembly of the solar car. The solar car was manufactured and driven inside Taibah University campus.

\section{Conclusions}

An implementation of virtual product development tools and procedures in an undergraduate capstone design project was presented. The class organization, policies, and procedures were presented in detail. The major challenges in the class implementation were presented. The impact of the proposed integration on the student learning outcome had been discussed. Integration between multidisciplinary teams was presented. After each year, the students comments on the project realize all the work they have done on such a complex project, how this course urged them to return to some of the concepts and theories they have learnt in various courses during the curriculum and how they are able to deal with that material to take decisions and reach the technical goal. The students appreciate the fact that they take their responsibility to achieve the team goals and objective. At the end of the second semester, the teams have been able to present collective reports that describe the design problem, alternative solutions, analyses and results, detailed final solution, and their prototype. Every member of the team participated in the realization of one part of the team project. The students appreciate the integration of virtual development into their project that allowed them to integrate their subsystems in the early stages of the design and avoid unnecessary iterations. Also, students were grateful that VPD tools helped them to tackle a challenging problem that never faced before.

\section{Conflict of Interests}

The author declares that there is no conflict of interests regarding the publication of this paper.

\section{Acknowledgment}

The author would like to thank his colleagues in the Mechanical Engineering Department: Dr. Mazharul Islam, Dr. Tarek Shehata, Dr. Naseer Ahmed, and Dr. Mobarak Al-Grafi for their effort during designing and manufacturing the solar car. The author would like to express thanks and appreciation to the former Dean of the Faculty of Engineering Dr. Saud Taher and the former Chairman of the ME department Dr. Yasir Sharif for their support during the implementation of this project. The author would like to extend thanks and appreciation to faculty members from the Electrical Engineering department: Dr. Samer Sharif, Dr. Ahmed Harb, and Dr. Ahmed Atieh.

\section{References}

[1] http://www.abet.org/eac-criteria-2014-2015/.

[2] PTC, "Concept design study uncovers opportunities for improvement, trends in concept design," PTC Study, July 2011, http://www.ptc.com/solutions/concept-design/trends/thank -you.ht.

[3] R. H. Todd, S. P. Magleby, C. D. Sorensen, B. R. Swan, and D. K. Anthony, "A survey of capstone engineering courses in North America," Journal of Engineering Education, vol. 84, no. 2, pp. 165-174, 1995.

[4] J. H. Bøhn, "Integrating rapid prototyping into the engineering curriculum-A Case Study," Rapid Prototyping Journal, vol. 3, no. 1, pp. 32-37, 1997.

[5] R. Žavbi and J. Tavčar, "Preparing undergraduate students for work in virtual product development teams," Computers and Education, vol. 44, no. 4, pp. 357-376, 2005.

[6] P. Schmidt, D. Sharer, D. Hoch et al., Implementation of a Capstone Senior Design Program Using Open Source Course Management Software, Conrad, James M.-Department of Electrical and Computer Engineering, University of North Carolina at Charlotte.

[7] W. Hills and J. W. Bull, "Innovative approach to integrating engineering design. The Newcastle Engineering Design Centre," Engineering Structures, vol. 23, no. 1, pp. 120-130, 2001.

[8] M. L. Cummings, "Integrating ethics in design through the value-sensitive design approach," Science and Engineering Ethics, vol. 12, no. 4, pp. 701-715, 2006.

[9] M. Wu and H. Yan, "System dynamics modeling and simulation in software engineering education," in Proceedings of the 9th International Conference for Young Computer Scientists (ICYCS '08), pp. 2407-2411, IEEE Computer Society, November 2008.

[10] D. Forney, A. Eid, T. Simiao et al., "Development of a device for attaching a wheelchair to a shopping cart or baby stroller," in Proceedings of the Rehabilitation Engineers Society of North America Conference (RESNA '07), Phoenix, Ariz, USA, June 2007.

[11] M. Franchetti, M. S. Hefzy, M. Pourazady, and C. Smallman, "Framework for implementing engineering senior design capstone courses and design clinics," Journal of STEM Education, vol. 13, no. 3, pp. 30-45, 2012.

[12] M. S. Hefzy, G. Nemunaitis, and M. Hess, "Design and development of a pressure relief seating apparatus for individuals with quadriplegia," Assistive Technology, vol. 8, no. 1, pp. 14-22, 1996.

[13] M. S. Hefzy, G. Nemunaitis, T. Jackman, and C. Csulik, "Crutch-like transfer block," in Proceedings of the Rehabilitation Engineers Society of North America Conference (RESNA '96), pp. 183-185, Salt Lake City, Utah, USA, June 1996.

[14] M. S. Hefzy, S. Killen, B. Dieddrich, K. Singer, and M. Forewerck, "Lift assist device," in Proceedings of the Rehabilitation Engineers Society of North America Conference (RESNA '96), pp. 186-188, Salt Lake City, Utah, USA, June 1996.

[15] M. S. Hefzy, A. Rizkallah, R. Evans, M. Recker, and G. Nemunaitis, "Accelerator control device," in Proceedings of the ASME International Mechanical Congress and Exposition, pp. 73-74, November 1995. 
[16] M. Hess, M. Klintworth, L. Simerlink et al., "Design and development of a pressure relief seating apparatus for quadriplegics," in Proceedings of the Bioengineering Conference, pp. 541-542, July 1995.

[17] B. Sanschagrin, C. Fortin, A. Vadéan, and A. Lakis, "Virtual product development within a fourth year option in the mechanical engineering curriculum," in Proceedings of the Canadian Design Engineering Network Conference (CDEN '05), Kaninaskis, Canada, July 2005.

[18] S. Beyerlein, D. Davis, M. Trevisan, P. Thompson, and K. Harrison, Assessment Framework for Capstone Design Courses, American Society for Engineering Education, 2006.

[19] M. Franchetti, "Evaluation of the effectiveness of the integration of a LITEE Case Study for a freshman level mechanical engineering course at The University of Toledo," Journal of STEM Education, vol. 12, no. 3, 2011.

[20] T. A. Warda, "Common elements of capstone projects in the world's top-ranked engineering universities," European Journal of Engineering Education, vol. 38, no. 2, pp. 211-218, 2013.

[21] S. Howe, "Where are we now? Statistics on capstone courses nationwide," Advances in Engineering Education, vol. 2, no. 1, pp. $1-27,2010$.

[22] L. J. McKenzie, M. S. Trevisan, D. C. Davis, and S. W. Beyerlein, "Capstone design courses and assessment: A National Study," in Proceedings of the American Society of Engineering Education Annual, Conference \& Exposition, pp. 1545-1562, June 2004.

[23] R. H. Todd and S. P. Maglebya, "Elements of a successful capstone course considering the needs of stakeholders," European Journal of Engineering Education, vol. 30, no. 2, pp. 203-214, 2005.

[24] R. H. Todd, C. D. Sorensen, and S. P. Magleby, "Designing a senior capstone course to satisfy industrial customers," Engineering Education, vol. 82, no. 2, pp. 92-100, 1993.

[25] A. Kachra and K. Schnietz, "The capstone strategy course: what might real integration look like?" Journal of Management Education, vol. 32, no. 4, pp. 476-508, 2008.

[26] P. L. Schmidt and J. M. Conrad, "Capstone 101: a framework for implementation of an ABET-compliant capstone sequence," in Proceedings of the ASEE Annual Conference and Exposition, 2012.

[27] R. J. Fornaro, M. R. Heil, and A. L. Tharp, "Reflections on 10 years of sponsored senior design projects: students win-clients win!," Journal of Systems and Software, vol. 80, no. 8, pp. 12091216, 2007.

[28] G. S. Shrivastava, "ASCE Vision 2025 and the Capstone Design Project," Journal of Professional Issues in Engineering Education and Practice, vol. 139, no. 1, pp. 5-11, 2013.

[29] M. M. AlMadany, "On engineering education in the new century," in Proceedings of the 2nd International Conference on Engineering Education \& Training, Kuwait City, Kuwait, April 2007.

[30] R. M. Felder and R. Brent, "Designing and teaching courses to satisfy the ABET engineering criteria," Journal of Engineering Education, vol. 92, no. 1, pp. 7-25, 2003.

[31] R. M. Leicht, J. I. Messner, and U. Poerschke, "INVOLVE: developing interactive workspaces that impact communication 25 and task performance when using virtual prototypes".

[32] C. W. Swan, K. Paterson, O. Pierrakos, A. R. Bielefeldt, and B. A. Striebig, "ISES-A Longitudinal Study to measure the impacts of service on engineering students," in Proceedings of the 118th ASEE Annual Conference and Exposition, June 2011.
[33] A. Sripakagorn and K. Maneeratana, "Design as the priority for engineering education: an implementation in a senior project course," in Proceedings of the ASEE Annual Conference and Exposition, June 2010.

[34] O. J. Helweq, "Teaching values in engineering ethics," in Proceedings of the 4th Christian Engineering Conference, pp. 3741, The Presbyterian College, June 2002.

[35] Y. A. Khulief, "Ethics education for engineering students," in Proceedings of the 2nd Conference on Planning \& Development of Education and Scientific Research in the Arab States, February 2008.

[36] C. B. Fleddermann, Engineering Ethics, Pearson Prentice Hall, 2004.

[37] B. Karagzoğlu, "Educating the ethical dimension of engineering to a muslim engineer," Journal of King Saud UniversityEngineering Sciences, vol. 18, no. 2, pp. 3-16, 2007.

[38] O. O. Khalifa, M. Hrairi, and A. Albagul, "Ethics in computer and information engineering education: case study," in Proceedings of the 2nd International Conference on Engineering Education \& Training, Kuwait City, Kuwait, April 2007.

[39] P. M. Griffin, S. O. Griffin, and D. C. Llewellyn, "The impact of group size and project duration on capstone design," Journal of Engineering Education, vol. 93, no. 3, pp. 185-193, 2004.

[40] S. C. Handrasekaran, A. M. T. Oo, A. Stojcevski, and G. Littlefair, "Best assessment practices of final year engineering projects in Australia," in Proceedings of the International Engineering and Technology Education Conference (IETEC'13), Ho Chi Minh City, Vietnam, 2013.

[41] M. Steiner, J. Kanai, C. Hsu, R. Alben, and L. Gerhardt, "Holistic assessment of student performance in multidisciplinary engineering capstone design projects," International Journal of Engineering Education, vol. 27, no. 6, pp. 1259-1272, 2011.

[42] M. Steiner, J. Kanai, R. Alben, L. Gerhardt, and C. Hsu, "A holistic approach for student assessment in project-based multidisciplinary engineering capstone design," in Proceedings of the ASEE Annual Conference and Exposition, June 2010.

[43] M. Khandaker, P. Orono, and S. Ekwaro-Osire, "Undergraduate engineering team projects: is there any correlation between presentation and participation?" in Proceedings of the ASEE Annual Conference and Exposition, June 2008. 

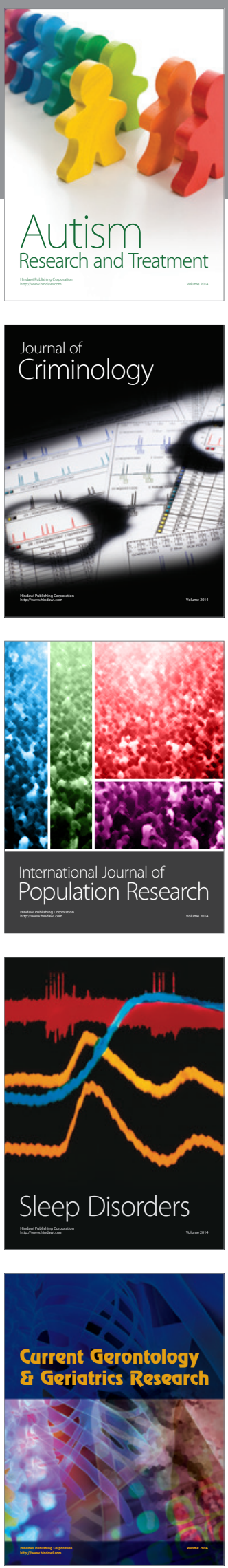
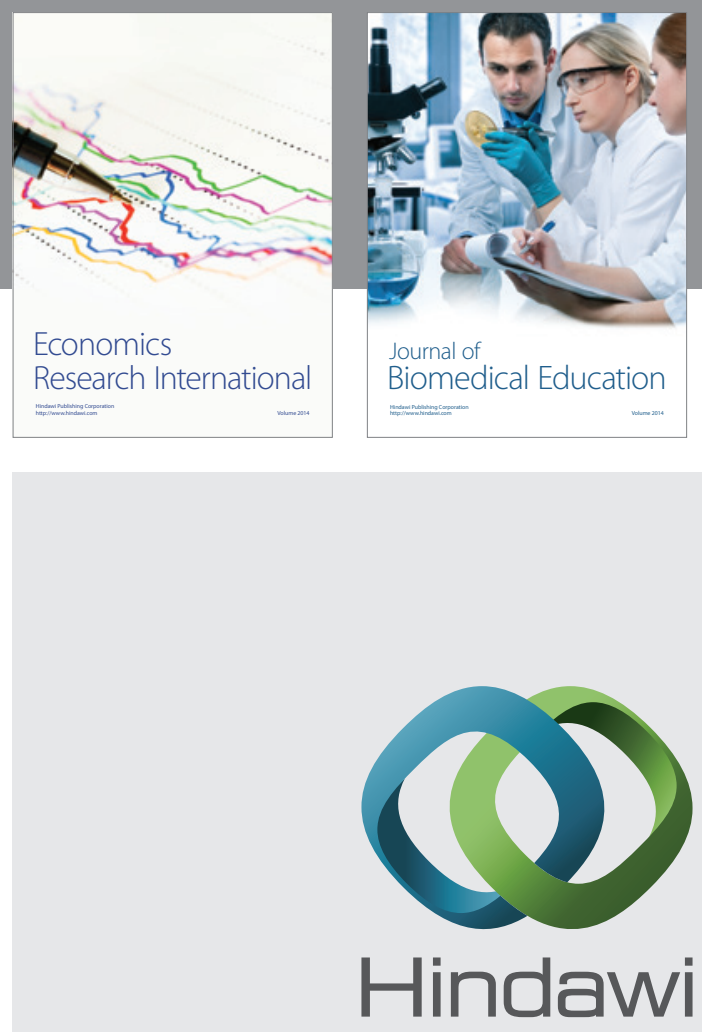

Submit your manuscripts at

http://www.hindawi.com
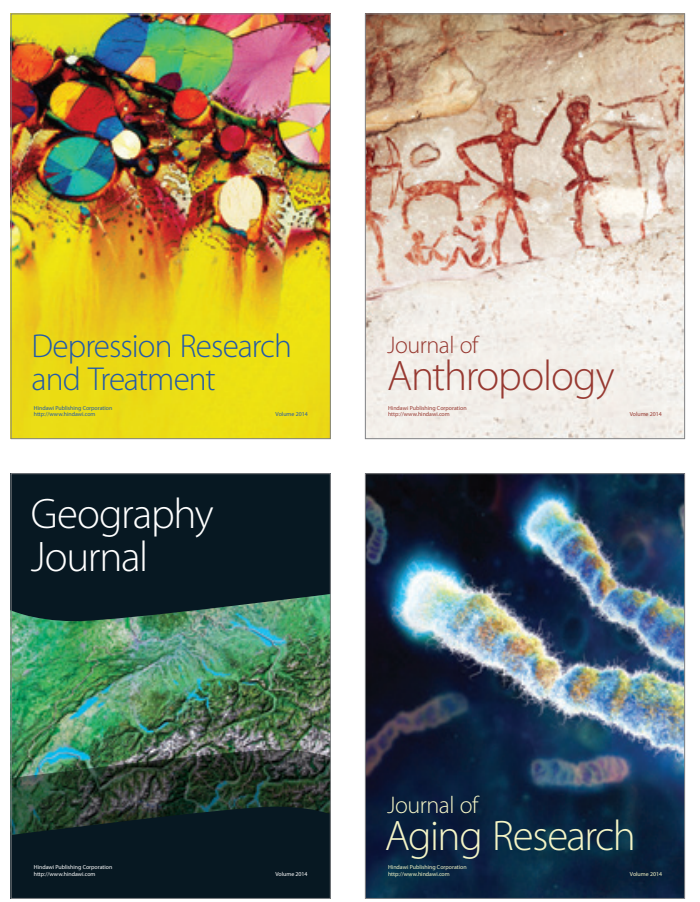
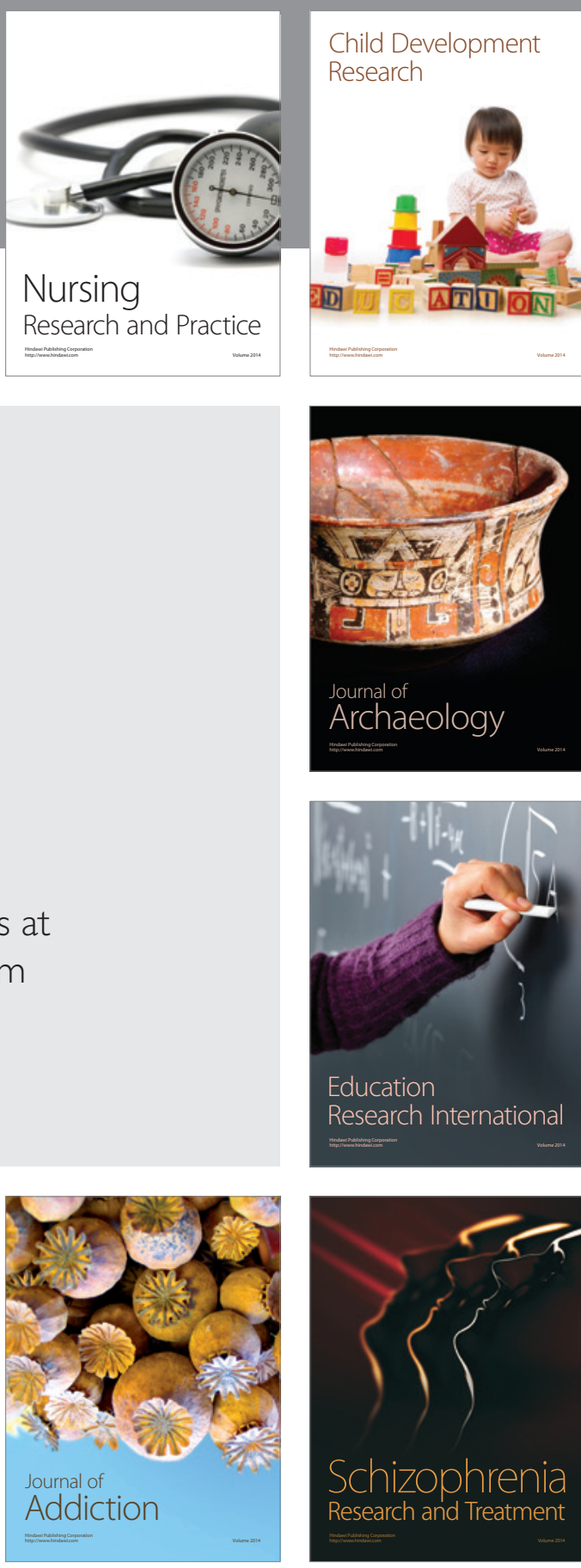

(D)
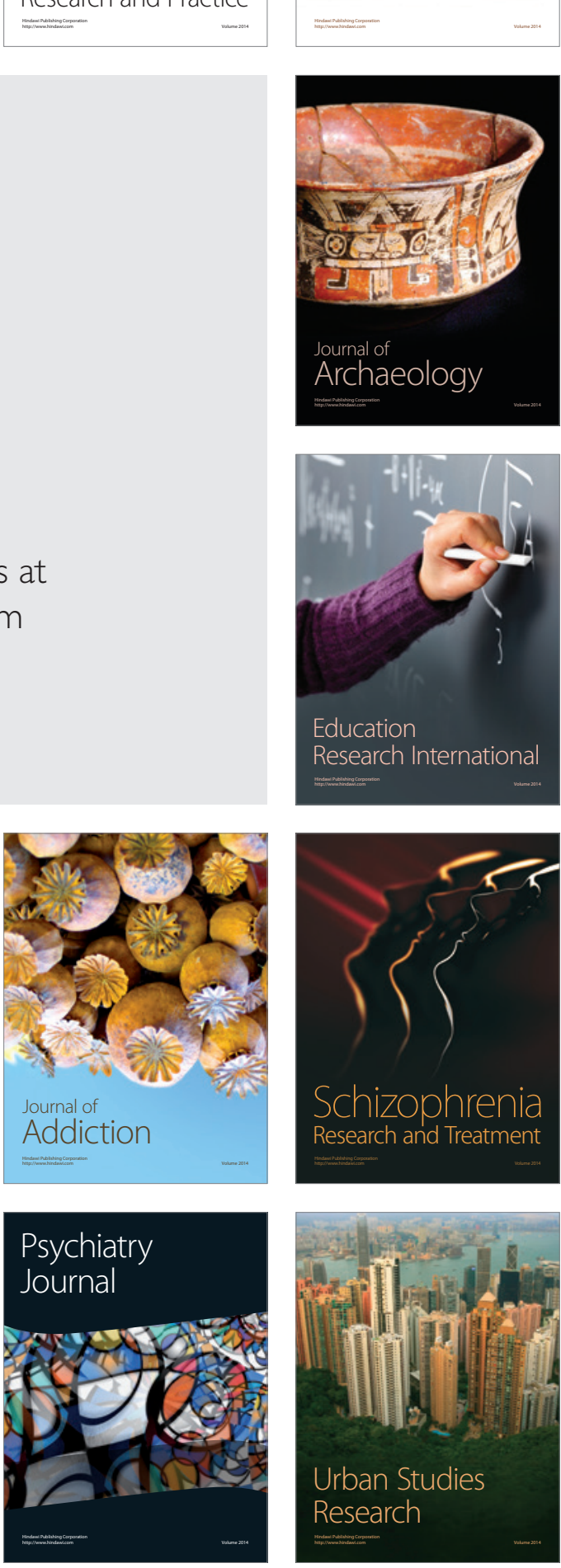